\title{
Food safety in Bangladesh: A microbiological perspective
}

\author{
Rashed Noor* and Farahnaaz Feroz \\ Department of Microbiology, Stamford University Bangladesh, 51 Siddeswari Road, Dhaka 1217, Bangladesh
}

Received 2 March 2016/Accepted 29 March 2016

\begin{abstract}
Bangladesh has long been facing problems associated with microbiological contamination of varieties foods due to the lack of awareness on hygiene followed by the defective legislative action. Manifestation of microbial prevalence in different foods bring about vital information on food safety as well as may envisage on the further intoxication caused by the prevailing microorganisms. Although a few extent of food inspection is apparently in some of the governmental regulatory bodies; however, the mass population is still suffering from a number of food borne illness. Present review partially focused on the microbiological regulation of the foods in Bangladesh and discussed the possible remedies for the maintenance of food safety.
\end{abstract}

Key words: Food safety; Food borne microorganisms; Food borne illness

\section{FOODBORNE MICROORGANISMS AND FOODBORNE ILLNESS}

Foodborne illness is also widely known as "foodborne disease," "foodborne infection," or "food poisoning (1). While most of the foodborne illnesses are acute, sometimes they may lead to more serious complications including haemorrhagic colitis, bloodstream infection, meningitis, joint infection, kidney failure, paralysis, miscarriage, and other complications (2-6). Indeed, the elemental prerequisite for leading a sound life depends on the sufficient reserve of quality food and water that are well controlled by various legislative bodies $(1,7-$ 10). However, pathogenic microorganisms together with fungal species, parasites, viruses, toxins, trace elements have been frequently reported to gain access into varieties of foods triggering the foodborne illnesses or infections $(8,11-22)$. As reported by a number of researches, foods are usually contaminated with microorganisms during the stages of harvesting, processing, storage, shipping, food preparation, kitchen utensils including the cutting boards or other surfaces, cross-contamination, etc. $(18,22-25)$.

The control of food contamination by microorganisms, or in other words, the practice of food protection largely depends on the types and modes of food hazards, the genetic makeup of the food contaminating bacteria or fungi, knowledge on toxins associated with food deterioration, and finally the urge

${ }^{*}$ Corresponding Author: Mailing address. Dr. Rashed Noor, Department of Microbiology, Stamford University Bangladesh, 51 Siddeswari Road, Dhaka 1217, Bangladesh, Bangladesh; E-mail: noor.rashed@yahoo.com. of practical implementation of food protection means both by the governmental or non-governmental organizations (NGOs) along with adequate research facilities on food microbiology (Figure 1).

Foodborne complications are of global public health concerns. While in the poor countries where hygiene maintenance is the principal reason of dissemination of diseases, surprisingly in the developed countries like United States, the impact of food borne diseases may also result in significant morbidity and mortality (1). However, certain regulatory bodies like the Center for Science in the Public Interest (CSPI), Centers for Disease Control and Prevention (CDC), FoodNet, etc., working with the food safety are actively engaged to control and monitor the food associated problems in the developed countries, whereas in the developing countries like in Bangladesh, such regulation is not that prominent to ensure the local health safety (Figure 2).

\section{FOOD SAFETY AND FOODBORNE ILLNESS: GLOBAL PERSPECTIVE}

In order to ensure a healthy and safe dissemination of food around the world, in 1962, the Food and Agriculture Organization (FAO) and the World Health Organization (WHO) jointly created the Codex Alimentarius Commission (CAC). Since then the Codex system has developed an array of general and commodity-specific standards, guidelines, codes of practice and other suggestions to enhance the global food safety. Indeed the food borne illness as well as the food safety is a mounting issue over the communities (26). According to the CAC, an international food standard setting authority developed 


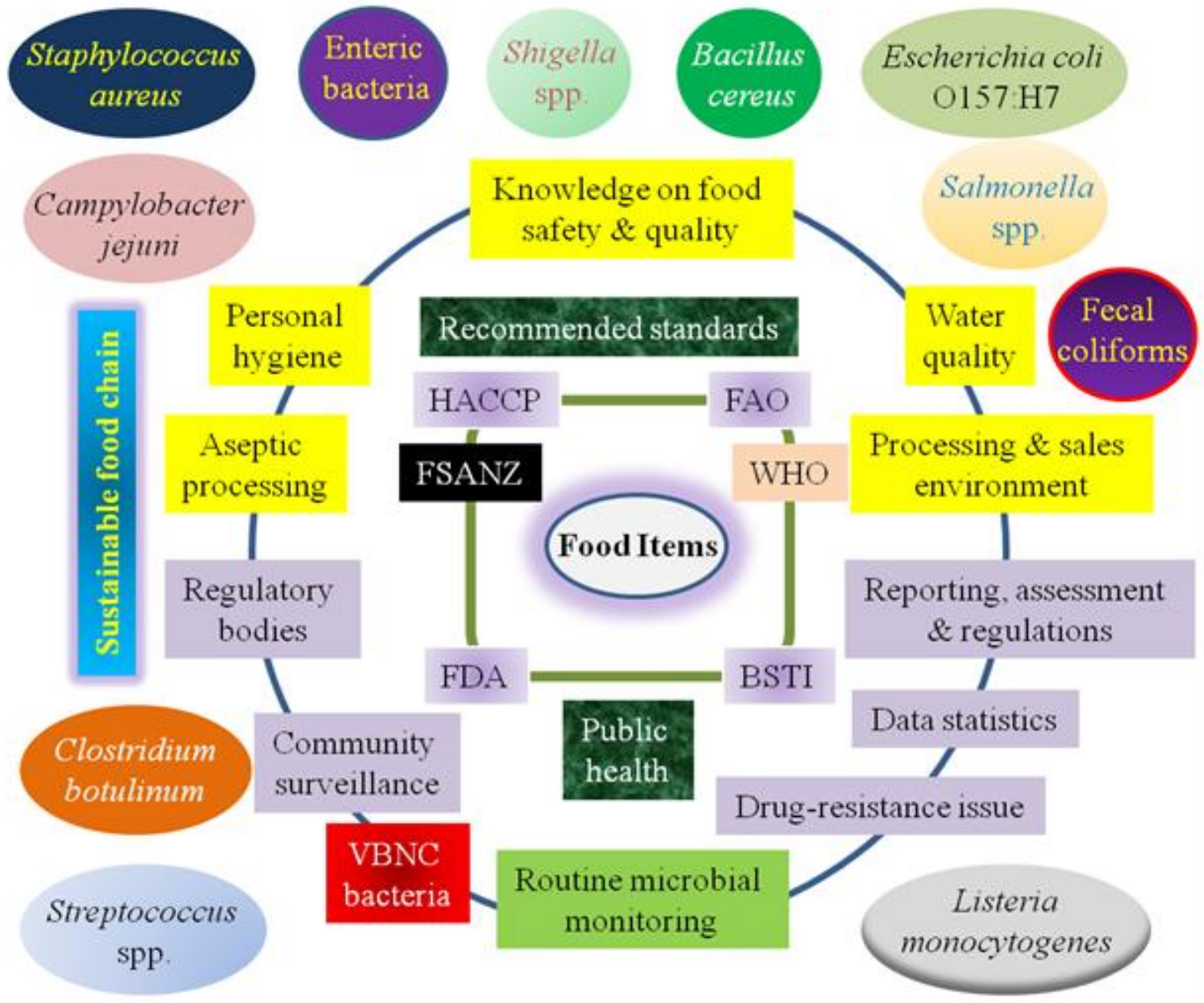

FIG. 1. General scheme showing the factors associated with food borne microbiological hazards. The proposed inter-connection between the international regulatory bodies (mainly FDA, WHO, FAO and HACCP), the recommended food borne microbial limits (principally set by FSANZ), and the Bangladeshi major food legislative organization, BSTI have been shown. Extrinsic factors including the knowledge on food safety, food processing water quality and other factors influencing food contamination have been noted to enhance the public awareness on hygiene practice as well as the aseptic handling of food items. The possible major microbial species including the VBNC bacteria contaminating foods have also been deciphered.

microbiological guidelines which include the formulation of design requirements, projected on the expected microbiological status of the food commodities, and finally focused on the verification of efficacy of hygienic practice $(7,27,28)$. However, the appropriate information or awareness of such guidelines are scarce not only in Bangladesh but also in other commodities especially within the East Asia region, resulting in food borne fatality with a relatively higher frequency compared to those in the developed countries. Nevertheless this is $\mathrm{t}$ be mentioned that several foodborne disease outbreaks like diarrhoea, cholera, salmonellosis, campylobacteriosis, and listeriosis have emerged as a major food borne health risk around the world. Hence, food safety is imperative public health precedence $(9,29)$.

The history of food borne disease outbreaks has long been known to the food microbiologists. According to the report stated in the Outbreak Alert (30), the worst foodborne disease outbreaks of the decade was noticed in May 2006, California State Prisons where Campylobacter contaminated pasteurized milk caused gastroenteritis among 1,644 prisoners. In April 2008, 1,535 people in 42 states in the USA have been affected by Salmonella typhimurium contaminated jalapeno and serrano peppers and pepper products. In 2011, Listeria contaminated 


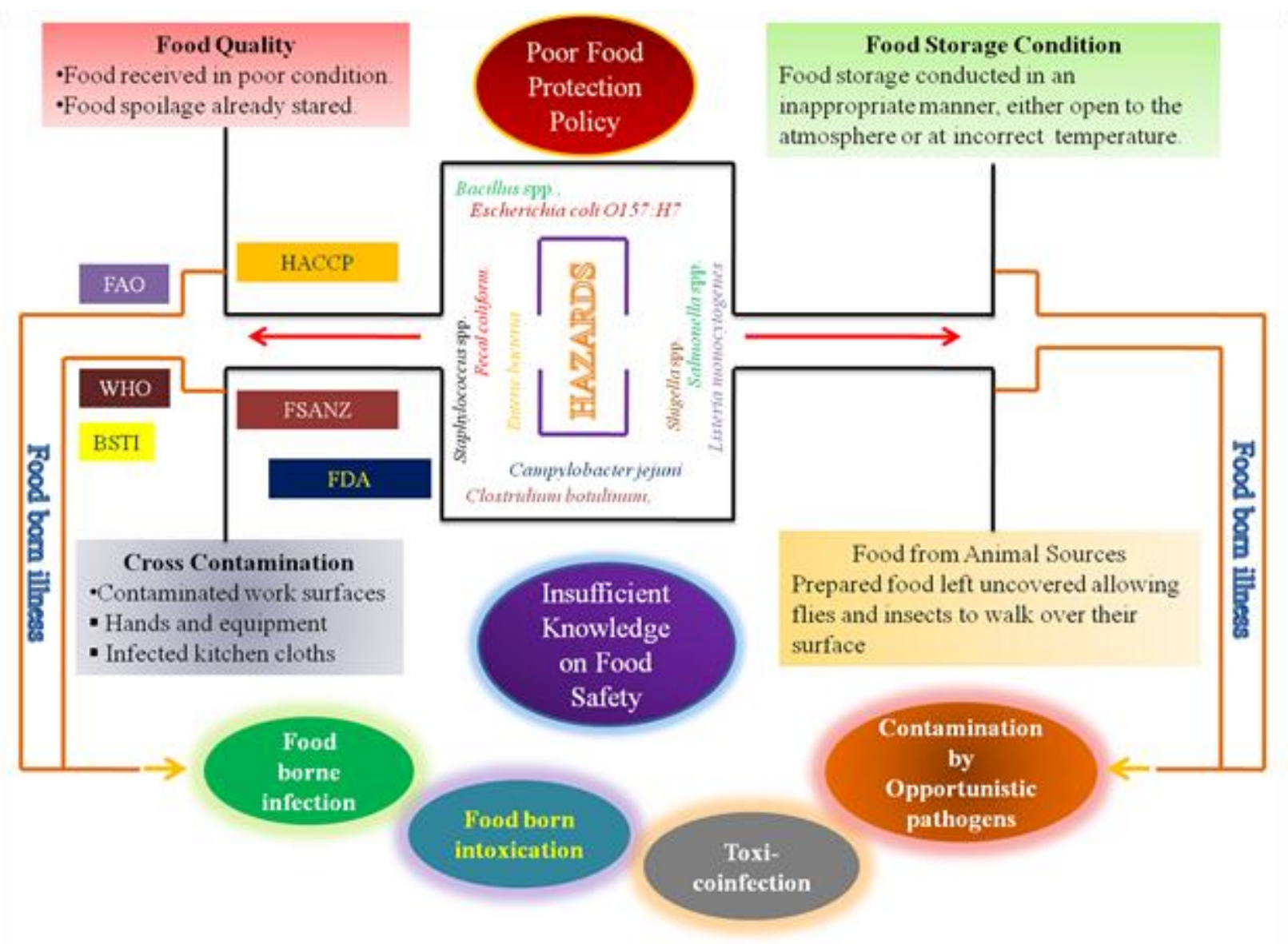

FIG. 2. Common aspects of the onset food borne disease outbreaks in Bangladesh. The schema emphasized on the lack of regulatory bodies in food protection as well as the impact of insufficient practice of unhygienic maintenance of food in triggering the food borne diseases: infection, intoxication, toxico-infection, and opportunistic infection of food items consumed.

cantaloupe was found to affect 148 people in 28 states, of which 30 people died (30). According to CDC (1) estimation, each year approximately $16 \%$ US people get sick from foodborne complications, 3,000 face death. The largest outbreaks of 2013 have been reported to be associated with Salmonella Heidelbergcontaminated chicken produced by California-based Foster Farms (30). Apart from USA, the other parts of the world have also revealed sufficient foodborne disease outbreaks $(12,23)$. To combat foodborne microorganism mediated disease outbreaks, the necessary risk assessment approach is now being applied to the microbiological safety of foods by several regulatory bodies as stated earlier (29). As stated earlier, such coordination or guidelines of risk management within food hazards in Bangladesh is also demanding.

\section{MICROBIOLOGICAL STATE OF COMMON FOODS IN BANGLADESH}

Among the disease conquered countries around the globe, Bangladeshi people are more likely to be prone to microbial attack due to the relatively dense population with extremely unhygienic sanitary facilities $(11,31,32)$. Several researches revealed that the propagation of waterborne microorganisms into the environment causing cholera and diarrhoea is very frequent in this country (3234). A recent estimation has revealed that approximately 30 million people in Bangladesh suffer from foodborne illnesses each year $(8,35)$. Besides, the National Taskforce on Food Adulteration (NTFS) made by the GoB found that adulterated foodstuffs each year causes various food borne enteric illnesses, malnutrition and other diseases leading to morbidity and mortality especially to the children (26, 36). Indeed, microbiologically contaminated water used for food processing as well as generated from the defective water distribution system is often responsible in conveying the enteric diseases within communities $(25,34)$. Water can harbor varieties of microorganisms including pathogenic strains of Escherichia coli, Salmonella spp., Vibrio cholerae, Shigella spp., Cryptosporidium parvum, Giardia lamblia, Cyclospora cayetanensis, Toxiplasma gondii and 
and the Norwalk and hepatitis A viruses. Minute amounts of contamination with some of these organisms can result in food borne illness leading to the dreadful impact on the mass public health (Figure 2).

A range of foods including the street vended food items or even foods supplied within the hospitals has been reported to be contaminated with an array of microorganisms including the faecal ones especially by the infected food handlers with deprived hygienic condition (37). In most of the cases, microbial studies have been carried out employing the selective and differential cultural media, the confirmative biochemical identification methods, and to some aspects, molecular studies have been conducted to demonstrate the virulent genes $(13,38-40)$. The fungal contamination aspects with the existence of mycotoxins have also been investigated to some extent.

\section{FOOD SAFETY REGULATION IN BANGLADESH: CURRENT CONCEPTS}

Food safety is an imperative issue in Bangladesh as there has been a long history of the countries to be victimized due to severe adulteration in foods resulting in fatality $(13,41,42)$. Several laws and constitutions including the Bangladesh Pure Food Ordinance, 1959, Bangladesh Pure Food Rules, 1967, the Food Grain Supply (Prevention of Prejudicial activity) Ordinance, 1956, the Radiation Protection Act, 1987, the Iodine Deficiency Disorders (IDD) Prevention Act, 1989, the Essential Commodity Act, 1990, and Fish and Fish product (Inspection and Quality Control) Rules, 1997exist in Bangladesh for items (42).

Within the framework of the Bangladesh Standards and Testing Institution Ordinance, 1985, the institution of Bangladesh Standards and Testing Institution (BSTI) has been established for standardization, testing and quality control, certifying the quality of commodities and materials, grading and marking of different goods. This is to be mentioned that the Ordinance has been amended as The Bangladesh Standards and Tasting Institution (Amendment) act, 2003 (42). Besides, more than dozen of laws deal with the food safety affairs excluding the common law provisions (26). The laws are principally implemented by several ministries and their subordinate bodies like the Parliament, Ministry of Agriculture (MOA), Ministry of Local Government, Rural Development and Co-operatives (MOLGRD), Ministry of Industry (MOI), Ministry of Fisheries and Livestock (MOFL), Ministry of Commerce (MOC), Ministry of Establishment (MOE) and Ministry of Home Affairs (MOHA) (26).

Despite the existence of several food controlling bodies, an official statistics published by the Ministry of Health and Family Welfare (MOHFW)
Government of Bangladesh (GoB) unraveled the case of adulteration of approximately half of the food samples tested by the laboratory of the Institute of Public Health (IPH) within the time frame of 2001 to 2009 (26). According to the report of the Directorate General of Health Services (DGHS), the enormity of the diarrhoeal diseases is caused principally by the unsafe foodstuffs. The report revealed around 18,000,000 people to suffer from diarrhoea from 2003 to 2009 (26). Unhygienic state of food as well as malnutrition largely account for this situation. Use of formalin, dichloro diphenyl trichloroethane (DDT) and toxic colors, or other forms adulteration within the food items may also trigger the enteric diseases, sleeping disorders, heart diseases and neurological diseases among the consumers (26, 27). General ignorance posed by the food industries towards the existing food regulations, regulatory failures, unexpected rise of food price, lack of consumer information, and educational and cultural state of the food handlers and the processors may trim down the required standards of food safety $(26,43,44)$. Moreover, the lack of coordination among the GoB agencies dealing with food safety may also result in the failure of the whole food safety arrangement in Bangladesh (26). Therefore, an effectual food safety regulatory structure is crucial to ensure the consistent supply of safe food items to the consumers. The accomplishment of the hazard analysis and critical control point (CCP) approach is fundamental to ensure a sound food safety management which in turn would define the control measures to reduce the foodborne microorganisms to an acceptable level (Figures 1 and 2) (45).

\section{CONTROL OF FOOD SPOILAGE MICROOGRANISMS: RECOMMENDATIONS}

Irrational increase in populations with the concurring food demand is a major problem in Bangladesh. The situation has been worsen with the use of polluted waters for food processing, lack of knowledge on the dietary intake of essential and toxic elements, and finally the scarcity in knowledge on hygiene. An efficient food safety regulatory framework is therefore of the essence to ensure the supply of safe foods to the consumers in a country (Figures 1 and 2). Currently, in Bangladesh the steadfast estimation of the public health blow due to the microbiological contamination of food is not available principally due to the lack of a regular monitoring system. Therefore, in perspective of Bangladesh, public health management and the mass awareness on hygiene are the principal concerns for eradicating foodborne diseases. Regulatory bodies and the Governmental health sectors should take necessary steps to furnish important information towards the general people about the sanitary condition of the food production and processing which in 
turn would minimize the risk of undergoing microbial infections. Establishment of the "Hazard Analysis: Critical Control Points" (HACCP) regulations should be endorsed at each step of food processing from the primary production, processing, manufacture, and distribution to the point of consumption.

Other measures for controlling the food quality as well as consumer safety should focus on the improvement of the surveillance of foodborne diseases, the judicious information on foodborne disease outbreaks as well as the food contamination events, setting and following the standards for the required quality of foods, development of the risk assessment measures for new food items, routine microbiological examination to ensure the safety of diverse food items, and finally building effectual communication on foodrelated risks are recommended. Lunching the facilities in the research laboratories for conducting sophisticated experiments relating molecular methods used to detect and identify foodborne pathogens are recommended (46).

From the view point of consumers, in order to avoid the foodborne illness, careful selection of foods for consumption is of prime importance. All raw foods must be appropriately checked for bacterial or fungal contamination specifically in premises where hygiene and sanitation are not sufficient enough to ensure the removal of food spoilage microorganisms. Undercooked food items must be avoided and it should be kept in consideration that even the cooked food that has been allowed to stand for several hours at ambient temperature can act as microbial media supporting microbial growth and hence should be thoroughly reheated before eating. Avoidance of taking street food is recommended since consumption of food and beverages obtained from street food vendors has frequently been associated with an increased risk of illness. In areas where the municipal supply water is at risk in microbiological perspective or the supply points are located at relatively unhygienic environments should be strictly avoided for drinking water. Offseason fruits and vegetables should be avoided since preservative chemicals are usually employed to maintain their apparent shelf life. Indeed, the general consciousness on health and hygiene would be the most valuable measure to keep safe from food borne infections and intoxications.

\section{CONCLUSION}

The necessity of identifying the possible areas for development within the regulatory affairs engaged in food protection in Bangladesh is of significant demand. Existing food microbiologists in Bangladesh, researchers interested to chalk out the problems associated with contaminated foods, and finally the general people are expected to heighten their consciousness on food safety. Indeed, the preliminary microbiological and biochemical researches followed by advanced genetic investigations on food contaminating agents should be expanded both in governmental and nongovernmental sectors to ensure the food safety, consumer safety and for the control of the steadiness of the mass population health.

\section{ACKNOWLEDGEMENT}

Authors acknowledge the research groups whose findings have been used to write this article.

\section{REFERENCES}

1. Centers for Disease Control and Prevention (CDC). 2014. Estimates of foodborne illness in the United States. CDC, Atlanta.

2. Center for Disease control and Prevention (CDC). 2011. Vital signs: incidence and trends of infection with pathogens transmitted commonly through food - foodborne diseases active surveillance network, 10 U.S. Sites, 1996 - 2010. Morbidity and Mortality Weekly Report. 60 (22): 749-755.

3. Henao OL, Scallan E, Mahon B, Hoekstra RM. 2010. Methods for monitoring trends in the incidence of foodborne diseases: Foodborne diseases active surveillance network 1996--2008. Foodborne Path. Dis. 7: 1421-6.

4. Hedberg CW, Smith SJ, Kirkland E, Radke V, Jones TF, Selman CA 2006. Systematic environmental evaluations to identify food safety differences between outbreak and nonoutbreak restaurants. J. Food Prot. 69 (11): 2697 702

5. US Food and Drug Administration (USFDA). 2013. Risk assessment for food terrorism and other food safety concerns.

6. World Health Organization (WHO). 2002. Food safety issues: terrorist threats to food, guidance for establishing and strengthening prevention and response systems. Food Safety Department, WHO Press, Geneva, Switzerland.

7. CAC (Codex Alimentarius Commission). 2007. Principles and guidelines for the conduct of microbiological risk management (MRM), CAC/GL-63. FAO, Rome.

8. FAO. (Food and Agriculture Organization of the United Nations). 2004. Worldwide regulations for mycotoxins in food and feed in 2003. FAO Food and Nutrition Paper, Rome, Italy.

9. FSANZ (Food Standards. Australia New Zealand). 2001a. Guidelines for the microbiological examination of ready - to - eat foods. Available at:http://www.foodstandards.gov.au/publications/pages/guidelinesformicrobi1 306.aspx. Accessed 18 October, 2014.

10. FSANZ (Food Standards Australia New Zealand). 2001b. Microbiological Limits for Food with guidelines criteria. 2001b. Available http://www.foodstandards.gov.au/code/Pages/default.aspx. Accessed 18 October, 2014.

11. Noor R, Feroz F. 2015. Requirements for microbiological quality management of the agricultural products: An introductory review in Bangladesh perspectives. Nutrition \& Food Science. 45 (5): 808-816.

12. Toyofuku H. 2014. Foodborne diseases: prevalence of foodborne diseases in western pacific region. Encyclopedia of Food Safety. 1: 312-322

13. Noor R, Hasan MF, Rahman MM. 2014. Molecular characterization of the virulent microorganisms along with their drug-resistance traits associated with the export quality frozen shrimps in Bangladesh. SpringerPlus. 3: 469.

14. Noor R, Uddin MA, Haq MA, Munshi SK, Acharjee M, Rahman MM. 2013a. Microbiological study of vendor and packed fruit juices locally available in Dhaka city, Bangladesh. International Food Research Journal. 20 (2): 1011-1015

15. Noor R, Acharjee M, Ahmed T, Das KK, Paul L, Munshi SK, et al. 2013b. Microbiological analysis of major sea fish collected from local markets in Dhaka city, Bangladesh. The Journal of Microbiology, Biotechnology and Food Sciences. 2 (4): 2420-2430.

16. Feroz F, Senjuti JD, Noor R. 2013. Determination of microbial growth and survival in salad vegetables through in vitro challenge test. International Journal of Nutrition and Food Science. 2 (6): 312-319.

17. Rahman F, Noor R. 2012. Prevalence of pathogenic bacteria in common salad vegetables of Dhaka Metropolis. Bangladesh Journal of Botany. 41 (2) 159-162.

18. Scannell AGM. 2011. Handbook of Food Safety Engineering. WileyBlackwell, Oxford, UK. 
19. Clark WF, Sontrop JM, Macnab JJ, Moist L, Suri R, Garg AX. 2010 Long term risk for hypertension, renal impairment, and cardiovascular disease after gastroenteritis from drinking water contaminated with Escherichia coli O157:H7: a prospective cohort study. British Medical Journal. 3 (41): c6020.

20. Milićević DR, Škrinjar M, Baltić T. 2010. Real and perceived risks for mycotoxin contamination in foods and feeds: challenges for food safety control. Toxins. 2: 572-592.

21. Senjuti JD, Feroz F, Tahera J, Das KK, Noor R. 2014. Assessment of microbiological contamination and the in vitro demonstration of the antibacterial traits of the commonly available local fruit blend within Dhaka Metropolis. Journal of Pharmacognosy and Phytochemistry. 3 (1): 73-77.

22. Frazier WC, Westhoff DC. 2007. Food Microbiology, $4^{\text {th }}$ ed. Tata McGraw-Hill, New Delhi, India.

23. Todd ECD. 2014. Foodborne diseases: Overview of biological hazards and foodborne diseases. Encyclopedia of Food Safety. 1: 221-242.

24. Acharjee M, Fatema K, Jahan F, Siddique SJ, Uddin MA, Noor R. 2013a. Prevalence of Vibrio cholerae in different food samples in the city of Dhaka, Bangladesh. International Food Research Journal. 20 (2): 1017 1022 .

25. Acharjee M, Rahman R, Beauty SA, Feroz F, Rahman MM, Noor R. 2011. Microbiological study on supply water and treated water in Dhaka city. Stamford Journal of Microbiology. 1 (1): 42-45.

26. Ali ANMA. 2013. Food safety and public health issues in Bangladesh: a regulatory. European Food and Feed Law Review. 8 (1): 31-40.

27. van Schothorst M, Zwietering MH, Ross T, Buchanan RL, Cole MB, International Commission on Microbiological Specifications for Foods 2009. Relating microbiological criteria to food safety objectives and performance objectives. Food Control 20: 967-79.

28. Food Administration Manual. 1995. Microbiological reference criteria for food. In: Microbiological Criteria, Version 2.0. pp. 1-25.

29. Ross T. 2014. Risk analysis: risk assessment: Microbiological hazards. Encyclopedia of Food Safety. 1: 80-92.

30. Outbreak Alert. 2014. A review of foodborne illness in America from 2002-2011, 16 ${ }^{\text {th }}$ ed. Center for Science in the Public Interest.

31. Noor R. 2016. Microbiological quality of commonly consumed street foods in Bangladesh. Nutrition \& Food Science. 46 (1): 130-141.

32. Alam MS, Feroz F, Rahman H, Das KK, Noor R. 2015. Microbiologica contamination sources of freshly cultivated vegetables. Nutrition \& Food Science. 45 (4): 646 - 658

33. Munshi SK, Rahman MM, Noor R. 2012. Detection of virulence potential of diarrheagenic Escherichia coli isolated from surface water of rivers surrounding Dhaka City. Journal of Bangladesh Academy of Sciences. 36 (1): 109-121.
34. Faruque SM, Sack DA, Sack RB, Colwell RR, Takeda Y, Nair GB. 2003. Emergence and evolution of Vibrio cholerae O139. PNAS. 100: 1304-1309.

35. Khairuzzaman M, Chowdhury FM, Zaman S, Mamun AA, Bari ML. 2014. Food safety challenges towards safe, healthy, and nutritious street foods in Bangladesh. International Journal of Food Science. DOI: http://dx.doi.org/10.1155/2014/483519

36. Khan F, Jolly YN, Islam GM, Akhter S, Kabir J. 2014. Contamination status and health risk assessment of trace elements in foodstuffs collected from the Buriganga River embankments, Dhaka, Bangladesh. International Journal of Food Contamination. DOI: 10.1186/s40550-014-0001-z

37. Sarker N, Islam S, Hasan M, Kabir F, Uddin MA, Noor R. 2013. Use of multiplex PCR assay for detection of diarrheagenic Escherichia coli in street vended food items. American Journal of Life Sciences. 1 (6): 267-272.

38. AFSSA (Agence Franc, aise de Se'curite' Sanitaire des Aliments). 2008. Technical guidance document on shelf-life studies for Listeria monocytogenes in ready-to-eat foods. Available at: http://ec.europa.eu/food/food/biosafety/salmonella/docs/shelflife. Accessed 19 October, 2014

39. APHA (American Public Health Association). 1998. Standard methods for the examination of water and wastewater, American Public Health Association: Washington, D.C.

40. Cappuccino JG, Sherman N. 1996. Microbiology - A laboratory manual. The Benjamin/Cummings Publishing Co., Inc., Menlo Park, California.

41. Acharjee M, Rahman F, Jahan F, Noor R. 2014. Bacterial proliferation in municipal water supplied in mirpur locality of Dhaka city, Bangladesh. Clean-Soil, Air, Water. 42 (4): 434-441.

42. Islam GMR, Hoque MM. 2013. Food safety regulation in Bangladesh, chemical hazard and some perception to overcome the dilemma. International Food Research Journal. 20 (1): 47-58.

43. Huda SSSM, Muzaffar AT, Ahmed JA. 2009. An enquiry into the perception on food quality among urban people: a case of Bangladesh. African Journal of Business Management. 3: 228.

44. Rahman MH, Alam MJB. 1997. Risk assessment of pesticides used in Bangladesh. Journal of Civil Engineering. 25 (1997): 97-106.

45. Ceuppens S, Li D, Uyttendaele M, Renault P, Ross $\mathbf{P}$, Ranst MV, et al. 2014. Molecular methods in food safety microbiology: Interpretation and implications of nucleic acid detection. Comprehensive Reviews in Food Science and Food Safety. 13: 551-577.

46. Noor R, Hasan MF, Munna MS, Rahman MM. 2015. Demonstration of virulent genes within Listeria and Klebsiella isolates contaminating the export quality frozen shrimps. International Aquatic Research. 7 (2): 157161. 